\title{
STRUKTUR SISTEM PANAS BUMI DAERAH CUBADAK BERDASARKAN PEMODELAN INVERSI 3-D DATA MAGNETOTELURIK
}

\section{CUBADAK GEOTHERMAL STRUCTURE BASED ON 3-D INVERSION OF MAGNETOTELLURIC DATA}

\author{
Wiwid Joni dan Tony Rahadinata \\ Pusat Sumber Daya Mineral, Batubara, dan Panas Bumi \\ joniwiwid@gmail.com
}

\begin{abstract}
ABSTRAK
Daerah panas bumi Cubadak terletak di Kabupaten Pasaman, Provinsi Sumatera Barat. Keberadaan sistem panas bumi di daerah Cubadak ditandai oleh munculnya mata air panas berupa mata air panas Cubadak, Sawah Mudik, dan Talu dengan temperatur antara $37,1^{\circ} \mathrm{C}$ dan $74,8^{\circ} \mathrm{C}$. Survei magnetotelurik (MT) telah dilakukan oleh Pusat Sumber Daya Mineral, Batubara, dan Panas Bumi, Badan Geologi, di daerah tersebut pada Tahun 2012, yang bertujuan untuk mengidentifikasi sistem panas bumi Cubadak. Penggunaan pemodelan inversi 3-D terhadap data MT diharapkan dapat mendelineasi dengan baik struktur sistem panas bumi Cubadak.

Berdasarkan pemodelan 3-D dihasilkan suatu struktur tahanan jenis, yang memiliki zona rendah (lebih kecil dari $11 \mathrm{Ohm}-\mathrm{m}$ ) di sekitar manifestasi panas bumi Cubadak dan Sawah Mudik, diinterpretasikan sebagai zona alterasi argilik, masing-masing mulai pada kedalaman 100 meter dan 250 meter, serta bertindak sebagai batuan penudung bagi sistem panas bumi Cubadak. Sementara itu, keberadaan top reservoir dari sistem tersebut diidentifikasi berada di bawah manifestasi Cubadak pada kedalaman 1.000 meter, sedangkan di bawah manifestasi Sawah Mudik pada kedalaman 1.250 meter.
\end{abstract}

Kata kunci: Cubadak, Sumatera, magnetotelurik, Inversi 3-D, panas bumi

\section{ABSTRACT}

Cubadak geothermal area is located in Pasaman Regency, West Sumatra province of Indonesia. The existence of geothermal system of the area is indicated by hot springs at the temperature varies from $31.7^{\circ} \mathrm{C}$ to $78.4^{\circ} \mathrm{C}$. A magnetotelluric (MT) survey has been conducted by Geological Agency in 2012 in order to identify the Cubadak geothermal system. By utilizing 3-D-inversion model of MT data we delineated a resistivity structure of the geothermal system.

The 3-D model of MT data result, a resistivity structure which indicates low zones $(<11 \mathrm{Ohm}$ $m$ ) around Cubadak and Sawah Mudik manifestations and interpretated to be correlated to as argillic alteration zones of the geothermal system at $100 \mathrm{~m}$ and $250 \mathrm{~m}$ underneath the manifestations respectively. Meanwhile, the existence of top reservoir is identified beneath the Cubadak manifestation at 1,000 meters depth and beneath Sawah Mudik manifestation at 1,250 meters depth.

Keywords: Cubadak, Sumatra, magnetotelluric, 3-D Inversion, geothermal 


\section{MAKALAH ILMIAH}

\section{PENDAHULUAN}

Sebagian wilayah Indonesia terletak pada busur vulkanik yang berpotensi memiliki energi panas bumi yang sangat besar. Salah satu potensi tersebut terdapat di daerah panas bumi Cubadak, Kabupaten Pasaman, Provinsi Sumatera Barat (Gambar 1).

Identifikasi keberadaan sistem panas bumi di daerah Cubadak ditandai oleh adanya manifestasi berupa kelompok mata air panas Cubadak dengan temperatur antara $68,4^{\circ} \mathrm{C}$ dan $74,8^{\circ} \mathrm{C}$, mata air panas Sawah Mudik dengan temperatur $31,7^{\circ} \mathrm{C}$, dan mata air panas Talu dengan temperatur $38,9^{\circ} \mathrm{C}$. Survei MT telah dilakukan oleh Pusat Sumber Daya Mineral, Batubara, dan Panas Bumi di daerah panas bumi Cubadak pada Tahun 2012, yang merupakan kelanjutan dari survei terpadu
3-G (geologi, geokimia, dan geofisika) pada Tahun 2008. Secara geografis, daerah survei berada pada koordinat 597600 - $617700 \mathrm{mT}$ dan 21200- 42500 $\mathrm{mU}$ pada proyeksi peta Universal Tranverse Mercator (UTM) Datum WGS 1984 zona $47 \mathrm{~N}$.

Hasil survei MT ini diharapkan dapat mencitrakan struktur tahanan jenis bawah permukaan sehingga dapat menginterpretasikan keberadaan dari sistem panas bumi di daerah Cubadak. Penulisan makalah ini bertujuan untuk memaparkan hasil inversi pemodelan 3-D data magnetotelurik melalui model struktur tahanan jenis secara vertikal dan lateral, yang dikorelasikan dengan data dukung geologi dan geokimia sehingga dapat memetakan kebaradaan sistem panas bumi Cubadak.

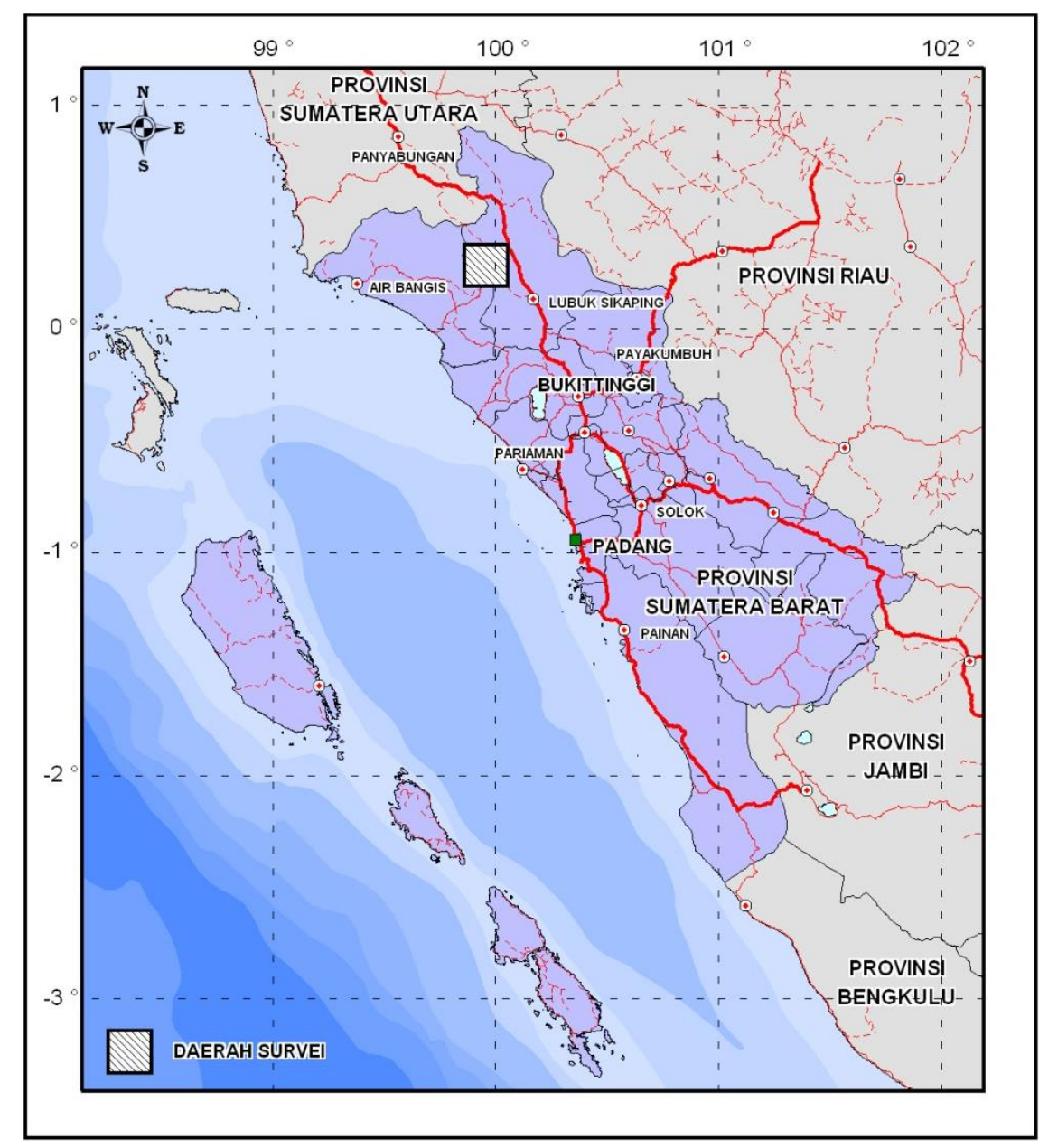

Gambar 1. Peta lokasi penyelidikan 


\section{METODELOGI}

\begin{abstract}
Metode MT adalah metode elektromagnetik (EM) pasif yang melibatkan pengukuran fluktuasi medan listrik $(E)$ dan medan magnet $(H)$ secara ortogonal pada permukaan bumi untuk menentukan struktur tahanan jenis dibawah permukaan bumi (Simpson dan Bahr, 2005).
\end{abstract}

Variasi medan magnet relatif kecil terhadap tahanan bawah permukaan sedangkan medan listrik secara langsung berhubungan dengan nilai tahanan jenis pada lokasi pengukuran (Cumming dan Mackie, 2010).

Struktur tahanan jenis terhadap reservoir panas bumi dikarakterisasikan oleh kombinasi zona alterasi sebagai lapisan penudung bertahanan jenis rendah yang kaya akan mineral lempung dan zona reservoir bertahanan jenis tinggi berada dibawahnya (Arnason dan Flovenz, 1992; Uchida dan Mitsuhata, 1995).

Hasil akuisisi data MT ini akan dilakukan pemodelan inversi untuk menghasilkan parameter model yang cocok dengan data, dimana selisih forward model dengan data harus diminimumkan atau disebut sebagai misfit function atau fungsi objektif (Grandis, 2009). Hasil inversi sangat bergantung pada forward model, yaitu perhitungan respon model dan sensitivitas, sehingga program matematis forward model yang efisien dan akurat adalah sangat penting. Dengan pendekatan numerik menggunakan metode Finite Difference menjadi solusi persamaan Maxwell (Siripunvaraporn, dkk., 2005).

Pemodelan inversi 3-D menggunakan perangkat lunak WSINV3DMT. Perangkat lunak tersebut merupakan kelanjutan dan implementasi dari inversi Occam 2-D (Siripunvaraporn dan Egbert, 2006). Penulis juga mengaplikasikan joint inversion dari data tensor impedansi dan matrik distorsi yang independen pada semua nilai frekuensi sehingga menghasilkan model konduktifitas/ resistivitas yang lebih baik terhadap inversi dari tensor impedansi MT tanpa melakukan koreksi akibat efek distorsi. Koreksi distorsi dapat digambarkan sebagai perkalian bilangan komplek tensor impedansi regional terhadap nilai matrik distorsi yang telah terkoreksi pada semua frekuensi. Dimana $Z(\omega)$ adalah bilangan komplek tensor impedansi regional, dan $C$ adalah nilai matrik distorsi yang telah terkoreksi pada semua frekuensi (avdeeva, a., dkk, 2015),

$$
C=\left(\begin{array}{ll}
C_{x x} & C_{x y} \\
C_{y x} & C_{y y}
\end{array}\right)
$$

$$
\begin{aligned}
& Z^{o b s}(\omega)=C Z(\omega) \\
& =\left(\begin{array}{ll}
C_{x x} Z_{x x}+C_{x y} Z_{y x} & C_{x x} Z_{x y}+C_{x y} Z_{y y} \\
C_{y x} Z_{x x}+C_{y y} Z_{y x} & C_{y x} Z_{x y}+C_{y y} Z_{y y}
\end{array}\right)
\end{aligned}
$$

Karena pemodelan ini pada dasarnya hanya menggunakan tensor impedansi data 2-D maka nilai $C_{x x}=C_{y y}=0$, dan juga nilai $Z_{x x}=Z_{y y}=0$

\section{TINJAUAN GEOSAIN}

Batuan tertua di daerah penyelidikan adalah batusabak berumur Permo-Karbon yang berada di bagian timurlaut daerah penyelidikan. Kegiatan tektonik terjadi sejak zaman Pra-Tersier sehingga ditemukan struktur-struktur berupa sesar normal dan sesar mendatar yang berarah baratlaut-tenggara, baratdaya-timurlaut dan utara-selatan yang bersamaan dengan pembentukan sesar besar Sumatera (Nurhadi, dkk., 2009).

Pada kala Eosen hingga Oligosen aktivitas tektonik memicu terjadinya terobosan magma ke permukaan yang menghasilkan batuan terobosan berkomposisi granodiorit di Bukit Rao. Sedangkan Pliosen hingga Plistosen terjadi pembentukan beberapa struktur sesar normal yang menyebabkan terbentuknya zona depresi Cubadak.

Produk vulkanik berupa aliran piroklastik adalah hasil erupsi celah yang terjadi 


\section{MAKALAH ILMIAH}

sepanjang jalur sesar selama masa Kuarter Awal dan mengisi hampir seluruh bagian dari zona depresi. Produk vulkanik lainnya yang terbentuk kemudian adalah aliran lava yang juga tersebar dari barat hingga timur daerah penyelidikan. Proses pengendapan endapan danau juga mengisi zona depresi di bagian baratlaut dan tengah hingga kala Holosen. Dan proses erosi yang berlangsung sampai saat ini menghasilkan endapan aluvium (Gambar 2).

Hasil analisis diagram segitiga $\mathrm{Cl}-\mathrm{SO}_{4}{ }^{-}$ $\mathrm{HCO}_{3}$ (Gambar 3) menunjukkan bahwa mata air panas Cubadak dan Sawah Mudik bertipe klorida-bikarbonat, sedangkan mata air panas Talu cenderung bertipe bikarbonat (Nurhadi, dkk., 2009).
Hasil diagram Na/1000-K/100- $\sqrt{ } \mathrm{Mg}$ menunjukkan bahwa mata air panas Cubadak berada pada zona batas partial equilibrium dan immature water, sedangkan mata air panas Sawah Mudik dan Talu berada pada zona immature water. Perkiraan temperatur bawah permukaan daerah Cubadak dengan menggunakan geotermometer $\mathrm{SiO}_{2}$ (conductive-cooling) berkisar 148 sd. $161^{\circ}$ C (entalphi sedang), sedangkan dengan menggunakan geotermometer $\mathrm{Na} / \mathrm{K}$ Giggenbach menghasilkan temperatur berkisar antara $218 \mathrm{sd}$. $250^{\circ} \mathrm{C}$, yang menunjukkan temperatur relatif cukup tinggi.

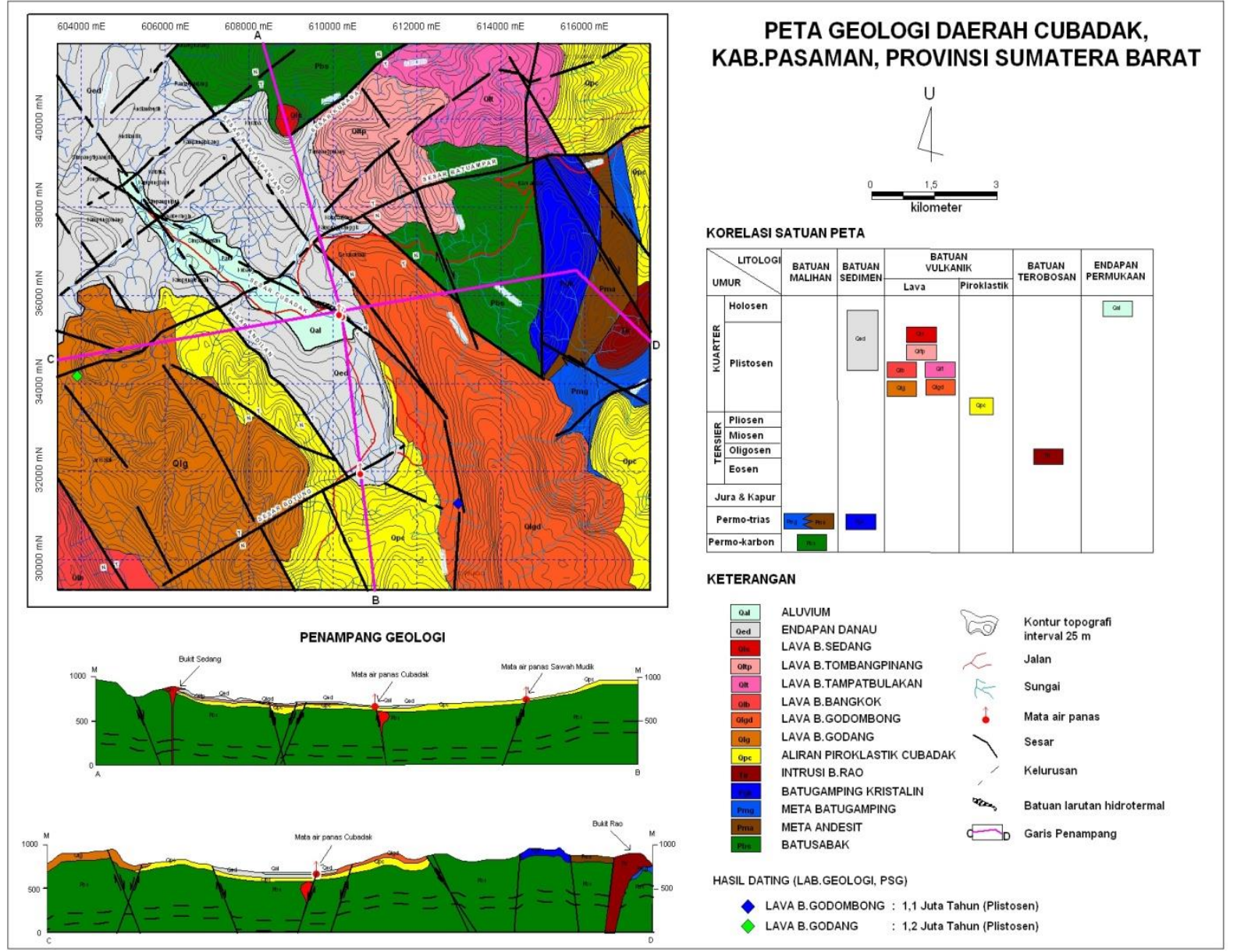

Gambar 2. Peta geologi daerah panas bumi Cubadak (Nurhadi, M., dkk, 2009) 


\section{MAKALAH ILMIAH}

\section{MODEL AWAL INVERSI 3-D}

Pada daerah penelitian ini telah dilakukan pengukuran MT sebanyak 39 titik pengukuran yang tersebar melingkupi daerah manifestasi Cubadak, dan Sawah Mudik (Gambar 4). Model awal 3-D dari data MT pada Gambar 5 dibuat dengan spasi grid 300 meter, dengan jumlah grid $40 \times 32$ sel dan dirotasi $315^{\circ}$ agar berarah baratlaut-tenggara atau sejajar dengan Sesar Sumatera (Vozoff, 2009). Pemodelan inversi ini hanya melibatkan impedansi tensor 2D dan menggunakan 12 frekuensi (97 hingga $0,04 \mathrm{~Hz}$ ).
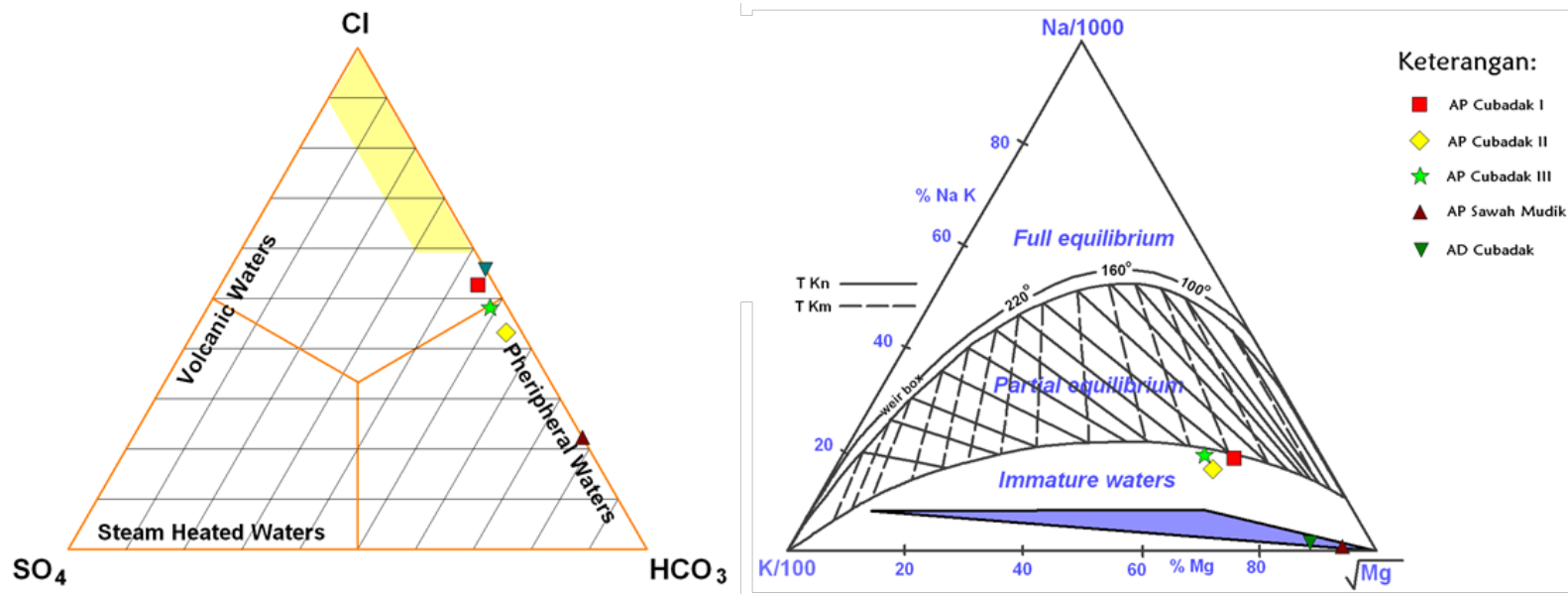

Gambar 3. Hasil diagram segitiga $\mathrm{Cl}-\mathrm{SO}_{4}-\mathrm{HCO}_{3}$ and Na-K-Mg (Nurhadi, M., dkk, 2009)

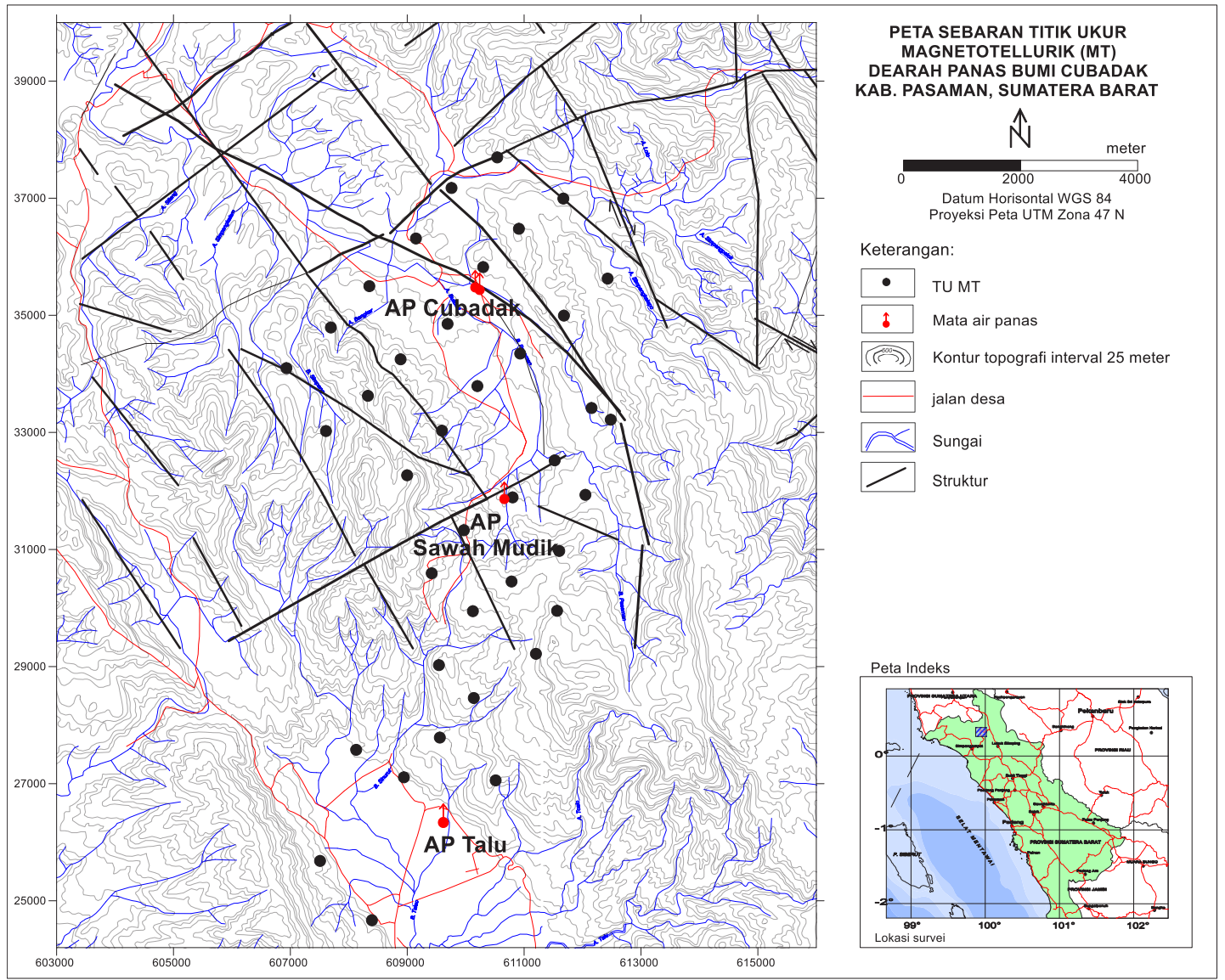

Gambar 4. Peta sebaran titik ukur MT 


\section{MAKALAH ILMIAH}



Gambar 5. Model awal untuk inversi 3-D, grid 300 meter, dengan jumlah grid $40 \times 32$ sel dan dirotasi $315^{\circ}$

\section{HASIL PEMODELAN 3-D DATA MT}

Hasil pemodelan inversi 3-D ini dipilih pada iterasi ke 7 dari 12 total iterasi yang dilakukan dengan rms error sebesar 2.56. Kurva tahanan jenis TE dan TM untuk membandingkan data observasi (data pengukuran) terhadap data kalkulasi (forward model) untuk beberapa titik pengukuran yang mewakili. Beberapa hasil kurva menunjukkan hasil kedua kurva yang relatif berimpit, namun beberapa data relatif berbeda seperti terlihat pada titik ukur MTCB-10, dan MTCB-38 (Gambar 6).

Hasil pengolahan data inversi 3-D kemudian dipetakan secara lateral pada kedalaman 100, 250, 500, 750, 1.000, 1.250, 1.500, dan 2.000 meter (Gambar 7). Pada kedalaman 100 meter, sebaran tahanan jenis rendah lebih kecil dari 11 Ohm-m terkonsentrasi di sekitar manifestasi Cubadak, sedangkan pada kedalaman $250 \mathrm{~m}$ tahanan jenis rendah tersebut meluas relatif ke arah selatan daerah penyelidikan yang diduga sebagai zona alterasi yang hampir mengisi seluruh bagian dari zona depresi dan bertindak sebagai batuan penudung bagi sistem reservoir panas bumi Cubadak. Pada kedalaman $500 \mathrm{~m}$, sebaran tahanan jenis rendah ini mulai meninggi di sekitar manifestasi Cubadak, namun di sekitar manifestasi Sawah Mudik semakin melebar ke arah barat dan timur daerah penelitian. Pada kedalaman 1.000 meter, sebaran tahanan jenis rendah di sekitar manifestasi Cubadak semakin meninggi $\geq$ 60 Ohm-m yang merupakan zona top reservoir dari sistem panas bumi, sedangkan sebaran tahanan jenis rendah di sekitar manifestasi Sawah Mudik semakin meninggi $\leq 60$ Ohm-m yang diduga sebagai zona transisi antara batuan penudung dan reservoir. Pada kedalaman 1.250 meter, sebaran tahanan jenis di sekitar manifestasi Sawah Mudik semakin meninggi $\geq 60$ Ohm-m yang diduga sebagai zona top reservoir dari sistem panas bumi. 


\section{MAKALAH ILMIAH}

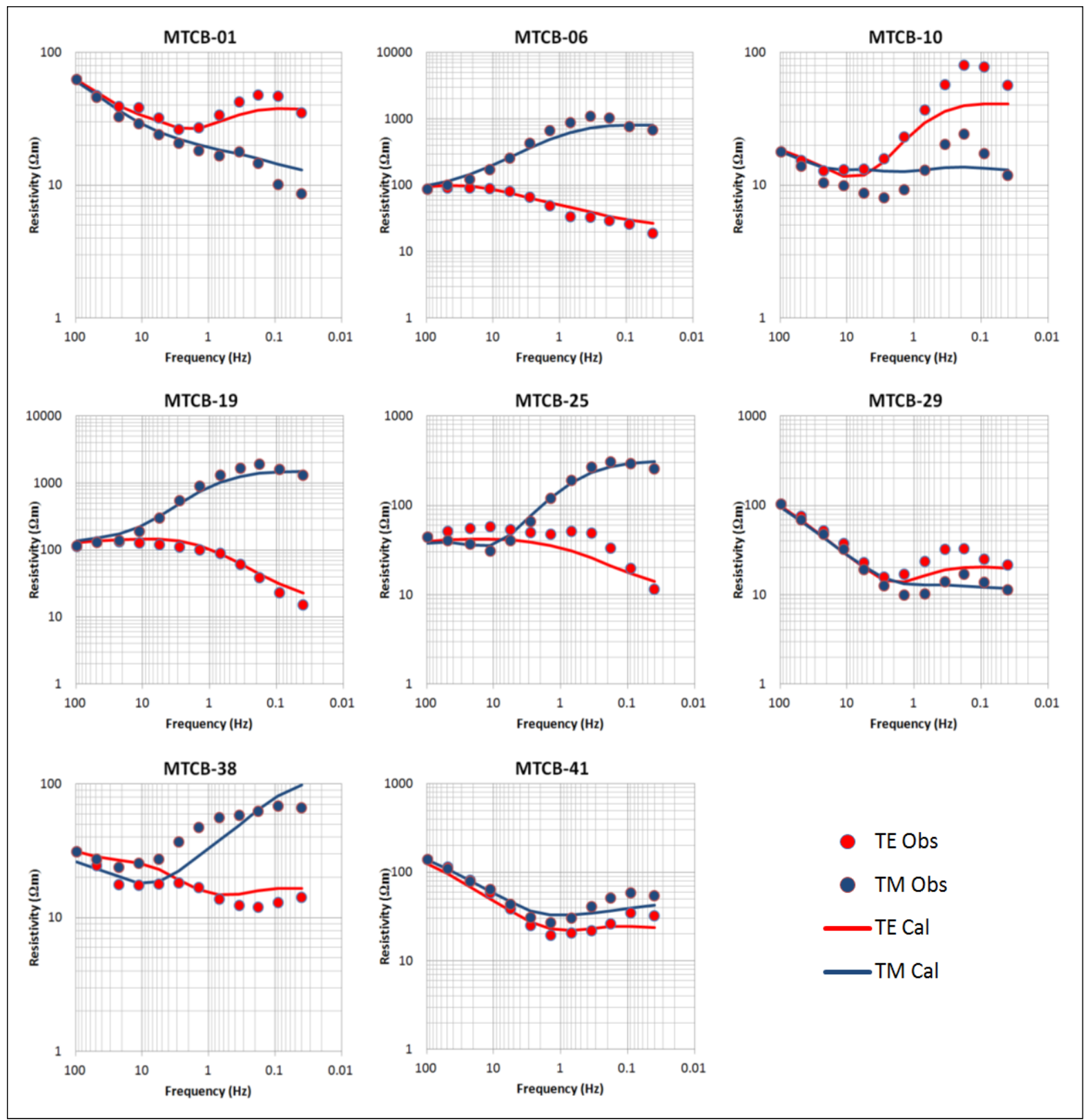

Gambar 6. Perbandingan respon kurva hasil Inversi 3-D terhadap data pengukuran pada beberapa titik ukur yang mewakili. 


\section{MAKALAH ILMIAH}

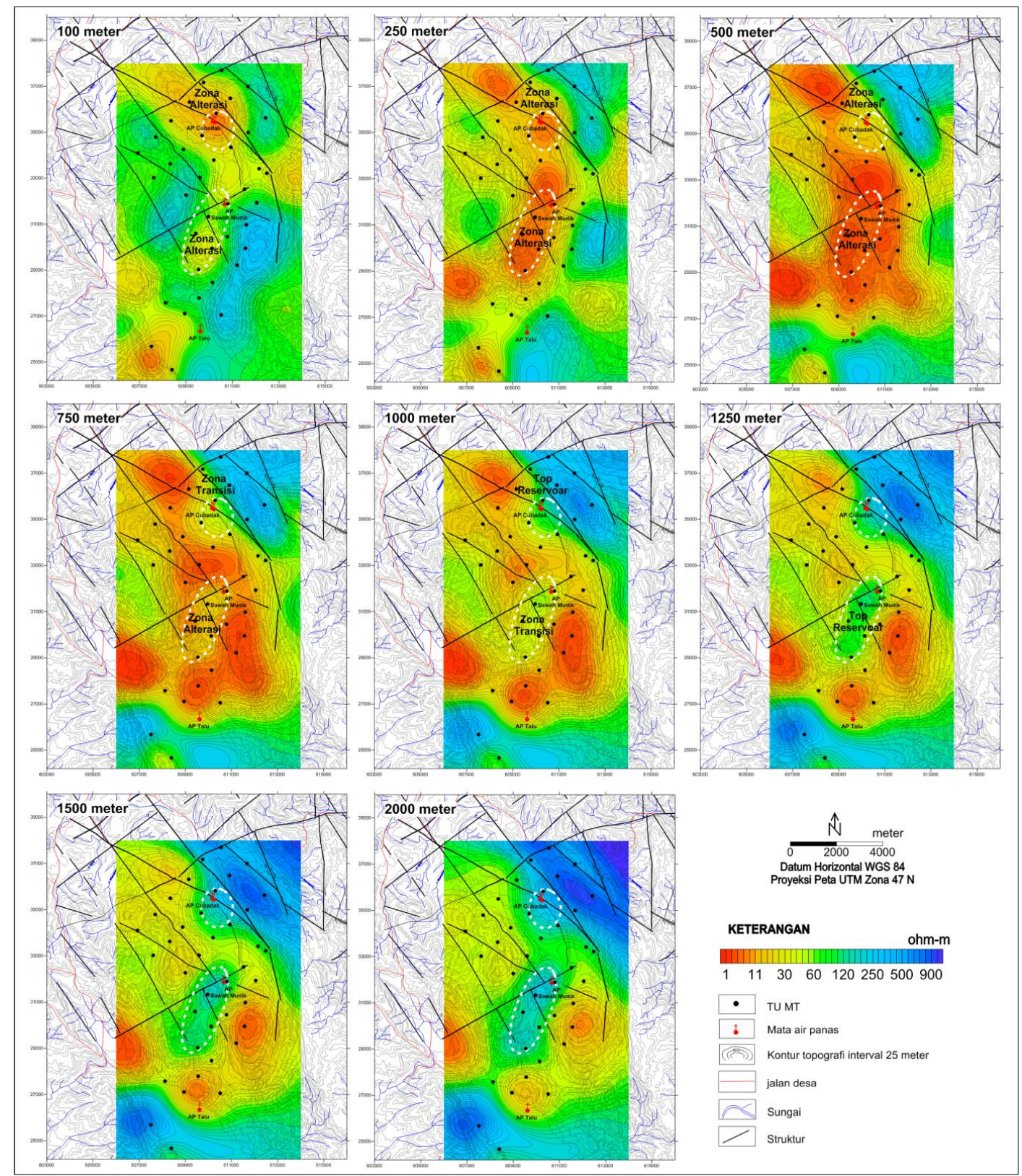

Gambar 7. Peta tahanan jenis hasil pemodelan 3-D dengan kedalaman bervariasi

Pada Gambar 8, hasil lintasan 2 menunjukkan bahwa lapisan tahanan jenis rendah lebih kecil dari 11 Ohm-m di bawah manifestasi Cubadak diduga sebagai lapisan penudung, sedangkan body bertahanan jenis tinggi dibagian timur laut diperkirakan sebagai respon batuan malihan yang bertindak sebagai batuan dasar di daerah penelitian. Lapisan tahanan jenis rendah lebih kecil dari 11 Ohm-m di bawah manifestasi Sawah Mudik pada lintasan 4 juga diduga sebagai lapisan penudung yang menerus hingga ke lintasan 5. Hasil lintasan 7 merupakan lintasan berarah selatan-utara yang hampir memotong keberadaan manifestasi Talu, Sawah Mudik, dan Cubadak yang terlihat zona sebaran tahanan jenis rendah lebih kecil dari 11 Ohm-m memiliki pola kemenerusan dan juga terlihat pada peta sebaran tahanan jenis pada kedalaman 500 meter (Gambar 6). Pola kemenerusan zona lapisan tahanan jenis rendah lebih kecil dari 11 ohm-m yang menerus ke arah manifestasi Talu diperkirakan sebagai respon dari aliran piroklastik Cubadak yang telah teralterasi. 


\section{MAKALAH ILMIAH}

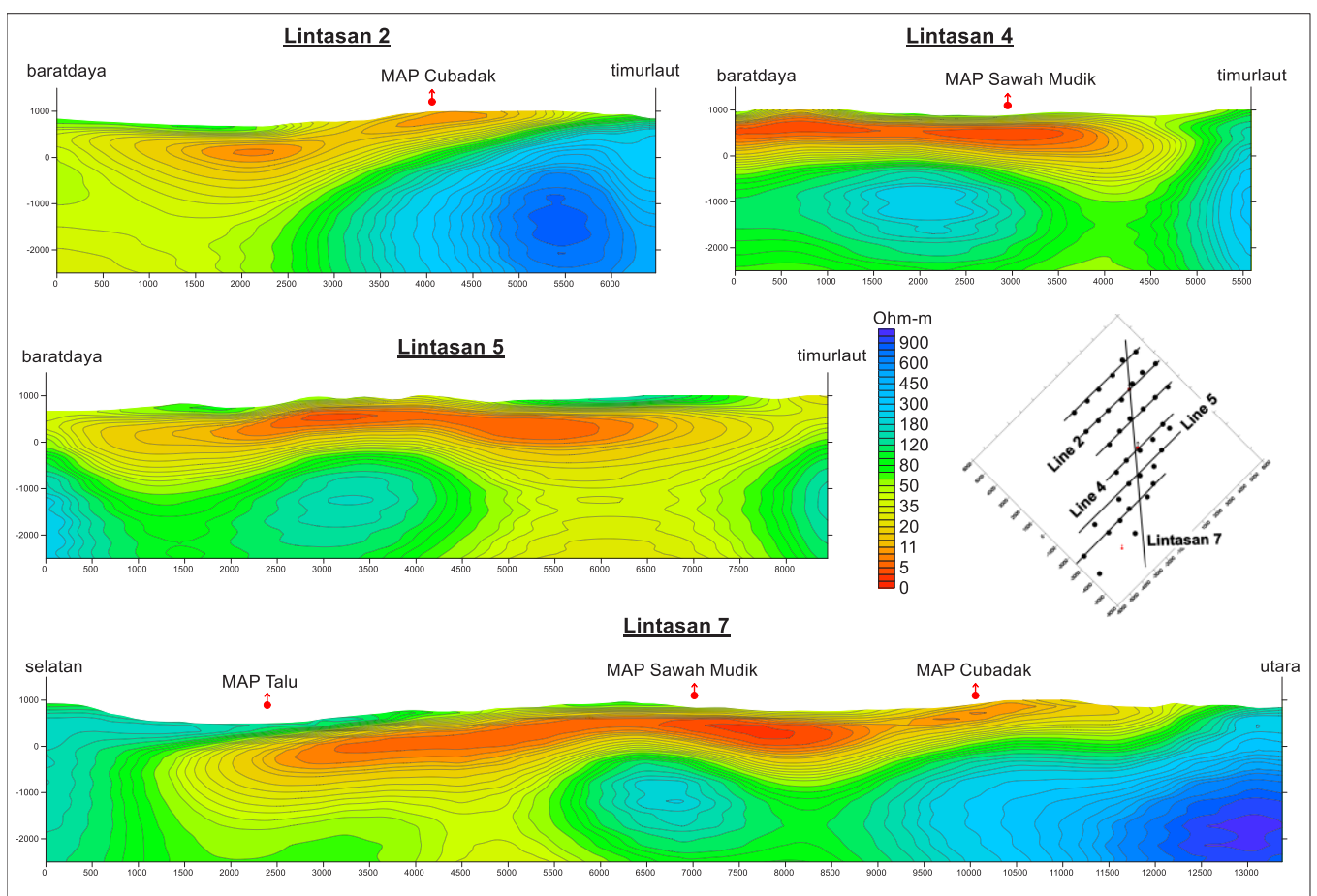

Gambar 8. Penampang tahanan jenis hasil pemodelan inversi 3-D pada lintasan 2, 4, 5, dan 7

\section{PEMBAHASAN}

Pembentukan sistem panas bumi daerah Cubadak diduga muncul akibat aktivitas vulkanik berupa erupsi celah. Erupsi celah ini menghasilkan tubuh-tubuh intrusi muda di lingkungan graben Cubadak, sehingga sisa panasnya diduga merupakan sumber panas untuk aktivitas sistem panas bumi ini. Keberadaan sesar Cubadak dan sesar Botung diduga merupakan struktur sesar yang mengontrol pemunculan mata air panas di daerah penyelidikan (Nurhadi, dkk., 2009).

Berdasarkan hasil data MT, keberadaan nilai tahanan jenis rendah di sekitar manifestasi Cubadak dan Sawah Mudik diduga sebagai zona alterasi argilik yang kaya akan mineral lempung yang bertindak sebagai batuan penudung dan berada pada satuan batuan piroklastik yang hampir mengisi seluruh zona depresi Cubadak. Keberadaan zona transisi di bawah manifestasi Cubadak terletak pada kedalaman 750 meter, sedangkan zona transisi di bawah manifestasi Sawah Mudik berada pada kedalaman 1.000 meter. Sebaran tahanan jenis $\geq 60 \mathrm{Ohm}$ - m di sekitar manifestasi Cubadak pada kedalaman 1000 meter, dan di sekitar manifestasi Sawah Mudik pada kedalaman 1.250 meter diduga sebagai zona alterasi propolitik yang diinterpretasikan sebagai puncak reservoir dari sistem panas bumi Cubadak. Keberadaan zona reservoir diduga berada pada satuan batusabak yang kaya akan rekahan dan bersifat permeabel, dimana batusabak ini diperkirakan sebagai batuan dasar di daerah penyelidikan.

Gambar 9 merupakan visualisasi hasil pemodelan inversi 3-D yang memotong keberadaan manifestasi Sawah Mudik. Lapisan tahanan jenis rendah lebih kecil dari 11 Ohm-m yang berada di bawah mata air panas Sawah Mudik hingga kedalaman 1.000 meter, telah terubah sifat fisis batuannya oleh fluida panas yang naik kepermukaan. Nilai tahanan jenis sedang $\geq 60 \mathrm{Ohm}-\mathrm{m}$ yang tertindih di bawahnya pada kedalaman sekitar 1.250 meter, diinterpretasikan sebagai top reservoir dari sistem panas bumi Cubadak. 


\section{MAKALAH ILMIAH}

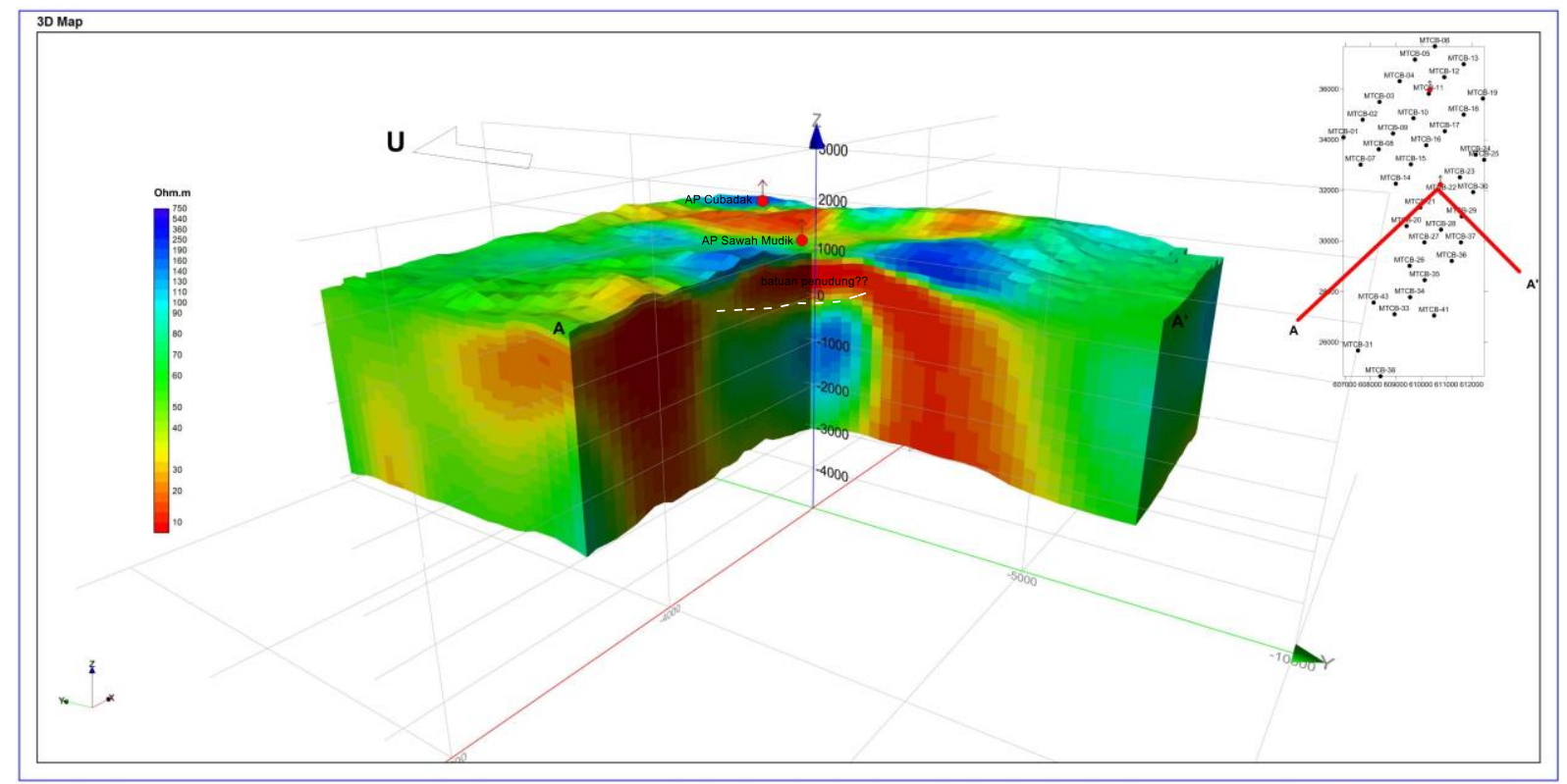

Gambar 9. Hasil Visualiasi pemodelan 3-D yang memotong keberadaan mata air panas Sawah Mudik.

\section{KESIMPULAN}

Keberadaan nilai tahanan jenis rendah lebih kecil dari 11 Ohm-m di sekitar manifestasi Cubadak dan Sawah Mudik diduga sebagai zona alterasi argilik dan bertindak sebagai lapisan penudung dari sistem panas bumi di daerah ini yang mulai terdeteksi pada masing-masing pada kedalaman 100 dan 250 meter. Sebaran tahanan jenis rendah tersebut meninggi $\geq 60$ Ohm-m di sekitar manifestasi Cubadak pada kedalaman 1.000 meter, dan di sekitar manifestasi Sawah mudik pada kedalaman 1.250 meter yang diinterpretasikan sebagai zona top reservoir dari sistem panas bumi Cubadak.

\section{UCAPAN TERIMA KASIH}

Penulis mengucapkan terima kasih yang sebesar-besarnya kepada Kepala Pusat Sumber Daya Mineral, Batubara dan Panas Bumi atas pemberian ijin untuk penulisan makalah ini. Penulis juga mengucapkan terima kasih yang sebesarbesarnya kepada Kepala Bidang Panas Bumi dan rekan-rekan di Bidang Panas Bumi yang telah bersedia berdiskusi dengan penulis.

\section{DAFTAR PUSTAKA}

Arnason, K., dan Flovenz, O.G., 1992, Evaluation of physical methods in exploration of rifted volcanic crust: Geothermal Resources Council Transactions, 16, 207-214.

Avdeeva, A., Moorkamp, M., Avdeev, D., Jegen, M., and Miensopust, M., 2015, Three-dimensional inversion of magnetotelluric impedance tensor data and full distortion matrix" Geophysical Journal International 202, 464-481.

Cumming, W., dan Mackie, R., 2010, Resistivity Imaging of Geothermal Resources Using 1D, 2D, and $3 D$ MT Inversion and TDEM Static Shift Correction Illustrated by a Glass Mountain Case History.

Grandis, H., 2009, Pengantar pemodelan inversi geofisika, Himpunan Ahli Geofisika Indonesia (HAGI).

Nurhadi, M., Widodo, S., Soetoyo, Sulaeman, B., 2009, Penyelidikan Terpadu Daerah Panas Bumi Cubadak, Kabupaten Pasaman, Sumatera Barat, Prosiding Hasil Kegiatan Lapangan Pusat Sumber Daya Geologi, Bandung. 


\section{MAKALAH ILMIAH}

Siripunvaraporn, W., Egbert, G., Lenbury, Y., Uyeshima, M., 2005, Three Dimensional magnetotelluric inversion: data-space method, Physics of the Earth and Planetary Interiors 150, 3-14.

Siripunvaraporn, W., 2006, WSINV3DMT version 1.0.0 for Single Processor Machine, User Manual, Department of Physics, Faculty of Science Mahidol University, Rama 6 Rd., Rachatawee, Bangkok 10400.
Simpson, F. and Bahr, K., 2005, Practical Magnetotellurics, University Press.

Uchida, T., and Mistsuhata, Y., 1995, Twodimensional inversion and interpretation of magnetotelluric data in the Sumikawa geothermal field, Japan: Geological Survey of Japan, Report Np. 282, 17-49.

Vozoff, K.,1990, Magnetotelluric: Principle and Practice, Volume 99, No 4, pp. 441-471, Proc. Indian Acad. Sci. (Earth

Planet.

Sci.).

\begin{tabular}{ll|} 
Diterima & $:$ 24 Januari 2018 \\
Direvisi & $:$ 12 Februari 2018 \\
Disetujui & $: 31$ Mei 2018 \\
\hline
\end{tabular}

